\title{
Effect of inulin, medium-chain triglycerides and whey protein isolate on stability and in vitro digestibility of enteral nutrition formulas
}

\author{
Mariana Wanessa Santana de SOUZA ${ }^{1}$ (D), Evelyn de Souza Oliveira LOPES ${ }^{1}$, Gustavo Pereira COSENZA ${ }^{1}$, \\ Verônica Ortiz ALVARENGA ${ }^{1}$, Renata Adriana LABANCA ${ }^{1}$, Raquel Linhares Bello de ARAÚJOㄹ, \\ Inayara Cristina Alves LACERDA ${ }^{1 \star}$
}

\begin{abstract}
This study aimed to evaluate the impact on digestibility and physical properties of enteral formulas by the addition of variable ingredients. Eight formulas were designed by a simplex-centroid evaluating different concentrations of inulin, medium-chain triglycerides (MCT) and whey protein isolate (WPI). Overall, the eight formulas developed presented mean values of $17.3 \%$ of protein, $62.3 \%$ of carbohydrates, $11.5 \%$ of lipids, a caloric value of $420 \mathrm{kcal} / 100 \mathrm{~g}$, thus obtaining nutritionally adequate formulas. The emulsion stability of the suspended formulas was affected by all ingredients and the interactions between MCT - inulin, and MCT - WPI were effective in improving this parameter. Besides that, the use of inulin mostly affected the protein digestibility, according to the degree of hydrolysis and the peptide profile. The desirability function $(d$-value $=0.769)$ proposed a formulation containing $0.70 \%$ of inulin, $1.56 \%$ of MCT, and $1.73 \%$ of WPI. This proposed solution may improve enteral formulas because this has optimal emulsion stability and protein digestibility, which are essential characteristics for a product to be used by patients under special clinical conditions.
\end{abstract}

Keywords: enteral formula; emulsion stability; in vitro gastrointestinal digestion; design of experiments.

Practical Application: Stability and protein digestibility of enteral formulas were affected by ingredient replacement.

\section{Introduction}

Enteral formulas are administrated for patients who are unable to consume conventionally food due to an illness condition. Many formulas have been developed to supplement nutrients to patients with these conditions. Also, they show prebiotic and pharmacological potential properties (Brasil, 2015; Brown et al., 2015; Pei et al., 2019; Zhuang et al., 2019). The digestibility and bioaccessibility are strongly influenced by their structure and composition (Mat et al., 2016; Simsek et al., 2017; Azzollini et al., 2018).

The nutrient absorption and digestion are two of the main criteria of enteral formula effectiveness. It can be measured by assessing some of their properties, such as digestibility and stability. These may be considered good indicators of their quality and potential consumer acceptance (Aguilera, 2018; Li et al., 2019).

The structure and composition of foods can significantly influence macronutrient digestibility of nutrients, and little is known about the mechanisms of this process. In vitro digestion protocols have been widely used for this evaluation and are relatively faster and less expensive than in vivo models (Minekus et al., 2014; Luo et al., 2015; Mat et al., 2016; Simsek et al., 2017).

Stability is directly related to the food matrix. It can be measured by assessing the complex assembly of nutrients and non-nutrients and how they interact. Chemical and physical variation in formulas influences their properties such as accessibility and digestibility (Aguilera, 2018). Enteral formulas are produced with standard ingredients or may contain specific added or replacing ingredients, aiming to improve its effectiveness (Savino, 2018; Portela et al., 2019).

Medium-chain triglycerides (MCT) are substances with 8-10 carbons which are absorbed faster than other types of lipids (Kinsella et al., 2017). They may reduce infection rates and improve hepatic, renal and immune function (Savino, 2018). Coconut and palm kernel oils are considered to be a good source of MCT (Marten et al., 2006; Food and Agriculture Organization \& World Health Organization, 2001).

Cheese whey is the major by-product in the manufacture of cheese and its use is of industrial interest, considering its nutritional value, besides being a strong agent of environmental pollution (Monteiro et al., 2018; Alves et al., 2019; Guimarães et al., 2019; Trindade et al., 2019). Whey proteins have high biological value, possess functional and bioactive properties, and may be a protein source for enteral formulas, due to the evidence that they increase the synthesis of protein and can promote better tolerance of enteral nutrition (Abrahão, 2012; Silva et al., 2014; Guimarães et al., 2019). Recently, there has been interest in using whey proteins and hydrocolloids in food beverages, because this interaction may play an important role in solutions stability (Ahmadi et al., 2018; Guimarães et al., 2018a). 
Inulin is one of the most used sources of dietary fiber in enteral formulas since it does not significantly interfere in the physical characteristics and stability compared to other fibers. It also provide a potential benefit in the prevention of diarrhea associated with enteral nutrition and may improve gastrointestinal health (Brown et al., 2015; Aydinol \& Ozcan, 2018; Guimarães et al., 2018b; Moghadam et al., 2019; Silva et al., 2019) being able to modulate the intestinal microbiota and by its prebiotic effects (Generoso et al., 2016; Jakobsen et al., 2017; Teimouri et al., 2018).

The improvement of the nutritional quality of enteral formulas is a great opportunity for both patients and food industries. So far, the influence of variable ingredients addition in enteral formulas is not clarified in literature. Therefore, this study emphasizes the understanding of the influence of carbohydrates, lipids and proteins modification on stability and nutritional properties of enteral formulas.

This study aimed to evaluate the impact of inulin, MCT and whey proteins on emulsion stability and protein digestibility of enteral formulas. Thus, we used a centroid multiplex to test the influence of each component over the formulas.

\section{Materials and methods}

\subsection{Experimental design and formulas development}

For enteral formulas development, a simplex-centroid design was used. To assess the impact of raw material, three independent variables: inulin $\left(\mathrm{I} ; X_{1}\right)$, medium-chain triglycerides $\left(\mathrm{MCT} ; X_{2}\right)$, and whey protein isolate (WPI; $X_{3}$ ) were used in different ratios (Table 1). The proportion for each variable ingredient was expressed as a fraction of the total mixture, and the sum was always equal to $4 \%$.

Each formula was produced in duplicate, and the results are reported as the average of the batches. Preliminary tests were carried out for the establishment of enteral formulas composition according to the Brazilian Regulation for enteral nutrition formulas, which establishes levels according to the Total Energy Content (TEC) of the product (Brasil, 2015). The proteins content should be between 10 and 20\%, lipids between 15 and $35 \%$, whereas carbohydrates should be from 45 to $75 \%$. The macronutrient levels were determined $\mathrm{n}$ order to remain within the limits established by legislation, even with the addition of different amounts of the variable ingredients. In addition to macronutrients, dietary fiber (up to $2.0 \mathrm{~g} / 100 \mathrm{kcal}$ ) may be added, and the formula containing the highest content (I), this parameter achieved $0.9 \mathrm{~g} / 100 \mathrm{kcal}$ (Brasil, 2015).
Then, the final formulations $(100 \mathrm{~g})$ were homogenized and stored in sealed aluminum foil bags $(195 \times 125 \mathrm{~mm})$ under refrigeration $\left(4^{\circ} \mathrm{C}\right)$.

\subsection{Physicochemical and rheological analysis}

The physicochemical analyses were carried out according to the Association of Official Analytical Chemists (2012). For moisture content, the samples were heated at $102{ }^{\circ} \mathrm{C}$ until constant weight and ashes were determined by incineration at $550^{\circ} \mathrm{C}$. For lipids, the analysis was carried out by Roese-Gottlieb method and proteins were determined by micro-Kjeldahl, using 6.38 as the conversion factor. The carbohydrates were estimated by difference in centesimal composition of enteral formulas.

The energy density was calculated by Atwater's factors. For $\mathrm{pH}$ measurement, the formulas were suspended in purified water $(1.0 \mathrm{kcal} / \mathrm{mL})$. Apparent viscosity was determined in Brookfield model DV-III viscometer (Middleboro, USA), spindle $\mathrm{CP} 40$ at $50 \mathrm{rpm}$, at $25^{\circ} \mathrm{C}$. All physicochemical measurements were done in triplicate, from two independent batches.

\subsection{Emulsion stability}

The emulsion stability was evaluated by droplet size and zeta potential. The droplet size distribution was determined by laser diffraction (LS 13 320, Beckman Coulter Life Sciences, Indianapolis, IN, USA). Purified water $\left(25^{\circ} \mathrm{C}\right)$, was used as a carrier agent for particle dispersion. The average diameter of the particles was determined based on the diameter of the same-volume sphere, De Brouckere diameter $\mathrm{D}_{4,3}$ presented in Equation 1 (Mugele \& Evans, 1951):

$$
D_{4,3}=\frac{\sum_{i=1}^{n} n \cdot d_{i}^{4}}{\sum_{i=1}^{n} n \cdot d_{i}^{3}}
$$

Where $d_{i}$, the diameter of the particles; $n$, number of particles.

Zeta potential was performed on a Zetasizer 3000HS (Malvern Instruments, Worcestershire, UK). The samples were diluted in ultrapure water $\left(10 \mu \mathrm{L} / 50 \mathrm{~mL}, 25^{\circ} \mathrm{C}\right)$. All measurements were taken in triplicate, from two independent batches.

\subsection{In vitro digestion}

Enteral formulas were digested in vitro according to the modified version of the standardized digestion method described by Minekus et al. (2014). For the simulated digestion phases, three stock solutions were prepared to simulate salivary (SSS),

Table 1. Variable ingredients (\%) used in the formulations according to the experimental design.

\begin{tabular}{crrrrrrrr}
\hline Variable ingredients & \multicolumn{1}{c}{ C } & I & M & W & IM & IW & MW & IMW \\
\hline Inulin $\left(X_{1}\right)^{\mathrm{a}}$ & 0.00 & 4.00 & 0.00 & 0.00 & 2.00 & 2.00 & 0.00 & 1.33 \\
MCT $\left(X_{2}\right)^{\mathrm{b}}$ & 0.00 & 0.00 & 4.00 & 0.00 & 2.00 & 0.00 & 2.00 & 1.33 \\
WPI $\left(X_{3}\right)^{\mathrm{c}}$ & 0.00 & 0.00 & 0.00 & 4.00 & 0.00 & 2.00 & 2.00 & 1.33 \\
TOTAL & 100.00 & 100.00 & 100.00 & 100.00 & 100.00 & 100.00 & 100.00 & 100.00 \\
\hline
\end{tabular}

WPI: Whey protein isolate; MCT: medium-chain triglycerides (palm kernel oil); C: control; I: inulin formula; M: MCT formula; W: WPI formula; IM: inulin and MCT formula; IW: inulin

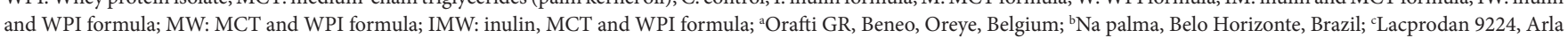
Foods, Denmark. 
gastric (SGS) and intestinal fluids (SIS). To simulate the oral phase, the samples were diluted in approximately $3 \mathrm{~mL}$ of SSS until obtaining a homogeneous paste, followed by the addition of $5 \mathrm{~mL}$ of $\alpha$-amylase solution (75 $\mathrm{U} \mathrm{mL}^{-1}$, Sigma-Aldrich A3176), at pH 7.0 for $2 \mathrm{~min}$. For the next phase, the simulated gastric solution containing pepsin $\left(2000 \mathrm{U} \mathrm{mL}^{-1}\right.$, Sigma-Aldrich, P7000) was added and $\mathrm{pH}$ adjusted to $3.0\left(\mathrm{HCl} 1 \mathrm{~mol} \mathrm{~L}^{-1}\right)$ and then incubated for $2 \mathrm{~h}$. Finally, to simulate intestinal digestion, SIS containing pancreatin (100 $\mathrm{U} \mathrm{mL}^{-1}$, Merck 1.07130) and bile (10 mmol L ${ }^{-1}$, Sigma-Aldrich B8631) was added, $\mathrm{pH}$ adjusted to $7.0\left(\mathrm{NaOH} 1 \mathrm{~mol} \mathrm{~L}^{-1}\right)$ and incubated for $2 \mathrm{~h}$. All steps were performed at $37^{\circ} \mathrm{C}$ under constant gentle agitation at $250 \mathrm{rpm}$ on a rotary shaking plate.

At the end of the procedure, the samples were centrifuged $\left(5000 \times g\right.$ for $5 \mathrm{~min}$ ) and the supernatant stored at $-20{ }^{\circ} \mathrm{C}$ for further analysis.

\section{Protein digestibility assay - degree of hydrolysis}

The degree of hydrolysis, before and after in vitro digestion, was measured by o-phthaldialdehyde (OPA) method as described previously by Morais et al. (2015).

\section{Protein digestibility assay - peptide profile}

For peptide profile, the samples were analyzed by Size-Exclusion High-Performance Liquid Chromatography (SE-HPLC). The analyses were done before and after digestion. It was performed in a PHEA column - poly (2-hydroxyethylaspartamide)-silica; $250 \times 9.4 \mathrm{~mm}$, $5 \mathrm{~mm}$ and $200 \AA$ A detection at $230 \mathrm{~nm}$. The samples were dissolved $(2 \% \mathrm{w} / \mathrm{v})$ in formic acid $\left(0.05\right.$ mol. $\left.\mathrm{L}^{-1}, \mathrm{pH} 2.5\right)$ mobile phase and filtered through a $0.22 \mu \mathrm{m}$ membrane. An aliquot $(10 \mu \mathrm{L})$ was injected at room temperature, under isocratic conditions, at a $0.7 \mathrm{~mL} \mathrm{~min}^{-1}$ flow rate for $30 \mathrm{~min}$ (adapted from Morais et al., 2015). Ubiquitin (8,560 Da), insulin chain B oxidized (3,495 Da), N-Hippuryl-HistidylLeucine (429.47 Da), and alanine (89.09 Da) (Sigma-Aldrich, St. Louis, MO, USA) were used as peptide size standards.

The peptide profile was quantified and compared, dividing into four fractions: F1 (>8.5 kD); F2 (3.5-8.5 kD); F3 (430 Da-3.5 kD); and F4 ( $<430 \mathrm{Da})$, according to the retention time of standards. Peak area (mAU.min) was calculated using Empower 3 Chromatography Data Software (Waters, USA). An example of the chromatograms obtained is shown in Supplementary Material.

\subsection{Statistical analysis}

Data were compared by unifactorial analysis of variances (ANOVA One-Way) and post hoc Tukey's test with a critical value of 0.05 . The effect of independent variables on the responses was evaluated by Response Surface Methodology (RSM), in agreement with the quadratic model, according to the Equation 2 (Karnopp et al., 2017):

$\hat{Y}=b_{1} x_{1}+b_{2} x_{2}+b_{3} x_{3}+b_{12} x_{1} x_{2}+b_{13} x_{1} x_{3}+b_{23} x_{2} x_{3}$

Where $\hat{Y}$ was the predicted response; $b_{1}, b_{2}, b_{3}, b_{12}, b_{13}$, and $b_{23}$ were the regression coefficients; and $\mathrm{x}_{1}, \mathrm{x}_{2}$, and $\mathrm{x}_{3}$ were the codified factors.

All data were analyzed using Statistica 10.0 (Statsoft Inc. South America, Tulsa, OK, USA) and SPSS 15.0 (SPSS Inc., Chicago, IL, USA) software.

\section{Results and discussion}

\subsection{Physicochemical and rheological analysis}

All physicochemical analyses (Table 2) indicated differences between the formulas, except for moisture content $(p=0.57)$ and ash $(p=0.07)$. The $\mathrm{pH}$ and apparent viscosity varied little, even though samples were statistically different $(p<0.001)$, with a mean value of $5.98( \pm 0.06)$ for $\mathrm{pH}$ and viscosity of $8.65( \pm 0.35) \mathrm{cp}$.

Vieira et al. (2018) evaluated the nutritional quality of enteral formulas, commonly administrated to Brazilian patients, in their reconstituted form. The formulas herein developed, also diluted (in an adequate concentration to reach $1.0 \mathrm{kcal} / \mathrm{mL}$ ), possess similar macronutrient composition, except for lipids content, which was less in the developed formulas (mean of $2.72 \mathrm{~g} / 100 \mathrm{kcal}$ ) than in the formulas analyzed by those authors $(4.3 \mathrm{~g} / 100 \mathrm{kcal})$. The great variability of commercial formulas, in terms of nutrition content, is to attend different clinical indication.

Table 2. Physicochemical and rheological characterization of the formulas.

\begin{tabular}{|c|c|c|c|c|c|c|c|c|}
\hline Formulas & Moisture (\%) & $\begin{array}{l}\text { Ash } \\
(\%)\end{array}$ & $\begin{array}{c}\text { Protein } \\
(\%)\end{array}$ & $\begin{array}{c}\text { Lipids } \\
(\%)\end{array}$ & $\begin{array}{c}\text { Carbohydrates } \\
(\%)\end{array}$ & $\begin{array}{c}\text { Energetic Value } \\
(\mathrm{kcal} / 100 \mathrm{~g})\end{array}$ & $\mathrm{pH}$ & $\begin{array}{c}\text { Apparent } \\
\text { viscosity }(\mathrm{cP})\end{array}$ \\
\hline $\mathrm{C}$ & $5.17 \pm 0.13^{\mathrm{a}}$ & $3.66 \pm 0.18^{\mathrm{a}}$ & $16.04 \pm 0.39^{c}$ & $10.52 \pm 0.40^{\mathrm{d}}$ & $64.61 \pm 0.77^{\mathrm{a}}$ & $417.24 \pm 2.32^{\mathrm{d}}$ & $5.98 \pm 0.02^{\mathrm{a}}$ & $8.22 \pm 0.24^{\mathrm{b}}$ \\
\hline I & $5.21 \pm 0.30^{\mathrm{a}}$ & $3.26 \pm 0.45^{\mathrm{a}}$ & $16.90 \pm 0.83^{b c}$ & $10.49 \pm 0.45^{\mathrm{d}}$ & $64.14 \pm 0.70^{\mathrm{ab}}$ & $409.35 \pm 2.83^{\mathrm{d}}$ & $6.04 \pm 0.08^{\mathrm{ab}}$ & $8.47 \pm 0.51^{\mathrm{ab}}$ \\
\hline M & $4.93 \pm 0.36^{\mathrm{a}}$ & $3.58 \pm 0.14^{\mathrm{a}}$ & $16.11 \pm 0.09^{c}$ & $14.07 \pm 0.18^{\mathrm{a}}$ & $61.32 \pm 0.36^{c}$ & $436.30 \pm 1.84^{\mathrm{a}}$ & $5.99 \pm 0.05^{\mathrm{ab}}$ & $8.77 \pm 0.17^{\mathrm{a}}$ \\
\hline $\mathrm{W}$ & $5.34 \pm 0.24^{\mathrm{a}}$ & $3.56 \pm 0.30^{\mathrm{a}}$ & $19.88 \pm 0.75^{\mathrm{a}}$ & $10.27 \pm 0.14^{\mathrm{d}}$ & $60.96 \pm 0.58^{c}$ & $415.74 \pm 1.48^{\mathrm{d}}$ & $5.93 \pm 0.05^{\mathrm{ab}}$ & $9.08 \pm 0.28^{\mathrm{a}}$ \\
\hline IM & $5.20 \pm 0.23^{\mathrm{a}}$ & $3.52 \pm 0.25^{\mathrm{a}}$ & $15.93 \pm 0.36^{c}$ & $12.33 \pm 0.32^{\mathrm{b}}$ & $63.02 \pm 0.51^{\mathrm{b}}$ & $422.20 \pm 2.04^{\mathrm{bc}}$ & $5.93 \pm 0.01^{\mathrm{b}}$ & $8.80 \pm 0.15^{\mathrm{a}}$ \\
\hline IW & $5.43 \pm 0.21^{\mathrm{a}}$ & $3.31 \pm 0.35^{\mathrm{a}}$ & $18.06 \pm 1.21^{\mathrm{b}}$ & $10.32 \pm 0.11^{\mathrm{d}}$ & $62.88 \pm 1.10^{\mathrm{b}}$ & $412.05 \pm 1.18^{\mathrm{d}}$ & $5.94 \pm 0.05^{\mathrm{ab}}$ & $8.65 \pm 0.18^{\mathrm{ab}}$ \\
\hline MW & $5.09 \pm 0.10^{\mathrm{a}}$ & $3.69 \pm 0.08^{\mathrm{a}}$ & $18.07 \pm 1.11^{\mathrm{b}}$ & $12.19 \pm 0.33^{b}$ & $60.96 \pm 1.26^{c}$ & $425.80 \pm 1.50^{\mathrm{b}}$ & $5.97 \pm 0.07^{\mathrm{a}}$ & $8.41 \pm 0.06^{\mathrm{a}}$ \\
\hline IMW & $5.17 \pm 0.23^{\mathrm{a}}$ & $3.46 \pm 0.19^{\mathrm{a}}$ & $17.02 \pm 0.41^{\mathrm{bc}}$ & $11.42 \pm 0.98^{c}$ & $62.92 \pm 1.04^{\mathrm{b}}$ & $419.49 \pm 4.83^{\mathrm{cd}}$ & $6.05 \pm 0.06^{\mathrm{ab}}$ & $8.85 \pm 0.35^{\mathrm{b}}$ \\
\hline p-value & 0.57 & 0.07 & $<0.001$ & $<0.001$ & $<0.001$ & $<0.001$ & $<0.001$ & $<0.001$ \\
\hline
\end{tabular}

${ }^{*}$ p-value by one-way ANOVA. Values are reported as mean \pm standard deviation of three replicates; Different letters in the same column represent significantly different values between samples. $(p<0.05)$. C: control; I: $4 \%$ inulin formula; M: $4 \%$ MCT formula; W: $4 \%$ WPI formula; IM: $2 \%$ inulin and $2 \%$ MCT formula; IW: $2 \%$ inulin and $2 \%$ WPI formula; MW: $2 \%$ MCT and $2 \%$ WPI formula; IMW: $1.33 \%$ inulin, $1.33 \%$ MCT and $1.33 \%$ WPI formula. 
The proposed mathematical model was not significant for apparent viscosity $(p=0.60)$ and $\mathrm{pH}(p=0.87)$ and only a part of the data variance could be explained $\left(R^{2}=0.406\right.$ for apparent viscosity and $\mathrm{R}^{2}=0.223$ for $\mathrm{pH}$ ), showing that the ingredients replacement did not affect these parameters.

\subsection{Emulsion stability}

The emulsion stability was evaluated on the diluted formulas, comparing then soon after dilution and after $24 \mathrm{~h}$, under refrigerated storage $\left(4^{\circ} \mathrm{C}\right)$. Except for the mean droplet size after $24 \mathrm{~h}$, the proposed mathematical model was not significant for the other analysis (initial droplet size and zeta potential), thus, these results will be discussed by mean comparison.

The initial droplet size (DS 0) showed that formulas $\mathrm{M}$ and IM, containing higher fat content (6.05 and $6.25 \mu \mathrm{m}$, respectively) presented a larger size than the others. Whereas those containing WPI resulted in smaller droplet size (W and IMW had 4.11 and $4.21 \mu \mathrm{m}$, respectively), possibly due to its emulsifying property, thus reducing fat droplets size (Figure 1A) (Nishanthi et al., 2018).

Shimokawa et al. (2017), analyzing enteral formulas with different emulsifiers, observed mean droplet size between 194 and $250 \mathrm{~nm}$, values over ten times smaller than those from this study (varying
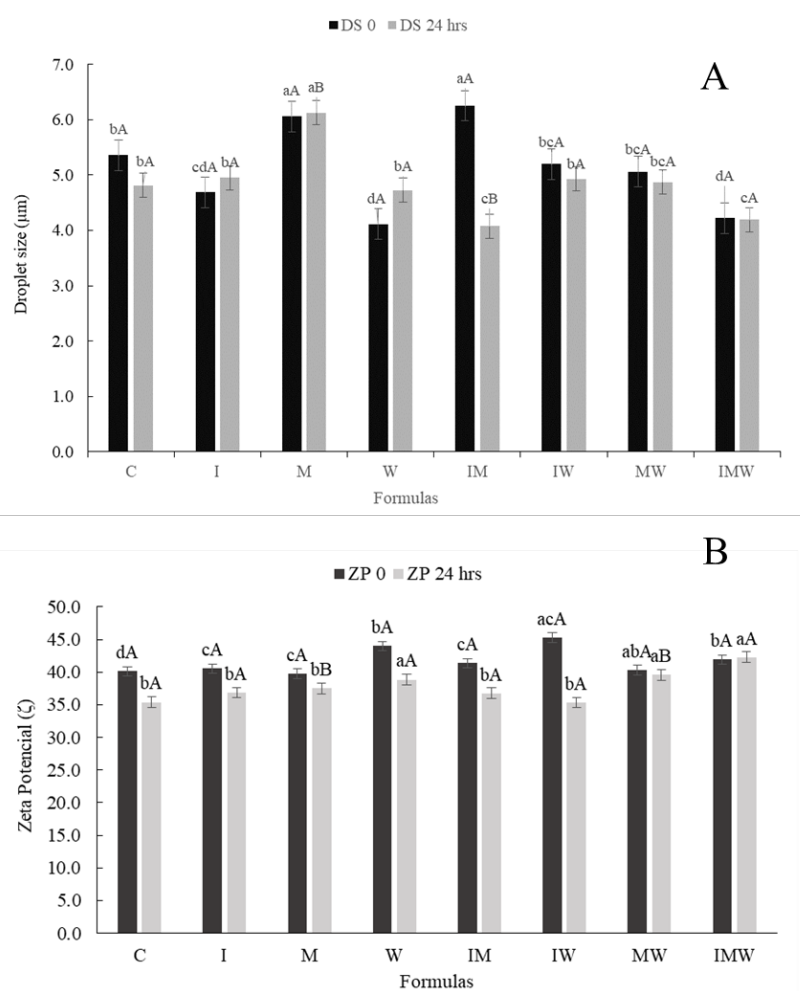

Figure 1. Mean droplet size (A) and zeta potential of the formulas (B), soon after its dilution in water and after 24 hours of refrigerated storage $\left(4^{\circ} \mathrm{C}\right)$. Different lowercase letters in the same column represent significantly different values between samples $(p<0.05)$; Different uppercase letters in the same line represent significantly different values for the same sample $(p<0.05)$. C: control; I: Inulin; M: MCT; W: WPI; IM: Inulin + MCT; IW: Inulin + WPI; MW: MCT + WPI; IMW: Inulin + MCT + WPI. from 4.11 and $6.25 \mu \mathrm{m}$ ). Nevertheless, the emulsification method used consisted of vigorous stirring (3000 rpm for $10 \mathrm{~min}$ ) and pressure homogenization $\left(500 \mathrm{kgf} / \mathrm{cm}^{2}\right)$. Since the aim of this study was to reproduce home and hospital conditions, a domestic mixer was used, explaining the differences found.

For the zeta potential of the formulas, the initial mean value ranged from -45.28 and $-39.75 \mathrm{mV}$. It is known that values above $30 \mathrm{mV}$, positively or negatively, are sufficient to ensure electrostatic stabilization (Castagnaro et al., 2013; Mohan et al., 2016). After $24 \mathrm{~h}$ of refrigerated storage, the values varied from -42.25 to $-35.33 \mathrm{mV}$, and as observed for droplet size, those containing higher fat content ( $\mathrm{M}$ and MW) had lower stability, demonstrated by the differences between values obtained initially and after 24 hours (Figure 1B).

Some high zeta potential values were found for the formulas containing WPI, and these results could be related to WPI negative charges above its isoelectric point (4.6) (Sriprablom et al., 2019). Since the formulas had a mean $\mathrm{pH}$ around 5.98, WPI influenced the zeta potential values, further reducing surface charges (Silvestre et al., 1999; González-Martínez et al., 2017).

A study performed by Wang et al. (2017) evaluated the influence of WPI and soybean lecithin on the stability of food emulsions. Similar results were observed, with zeta potential values around $-45.0 \mathrm{mV}$. The authors attribute the negative and relatively high zeta potential values to a $\mathrm{pH}$ close to neutrality (5.1), above the whey proteins isoelectric point.

For droplet size after $24 \mathrm{~h}$, at refrigerated storage $\left(4^{\circ} \mathrm{C}\right)$, the model was significant $(p<0.001)$ and explained the experimental data $\left(\mathrm{R}^{2}=0.9629\right)$. This demonstrated that all ingredients influenced the mean droplet size. The interactions between inulin and MCT, as well as MCT and WPI, played a significant role in reducing the values, improving emulsion stability (Figure 2).

These data support that the interaction between factors was most beneficial for emulsion stability, considering that association of inulin and MCT or MCT and WPI reduced droplet size. In these cases, inulin and WPI acted as emulsifying agents, active substances that can be absorbed in the oil droplet surface to produce an interfacial layer, providing electrostatic and steric stabilization (López-Castejón et al., 2019; Sriprablom et al., 2019).

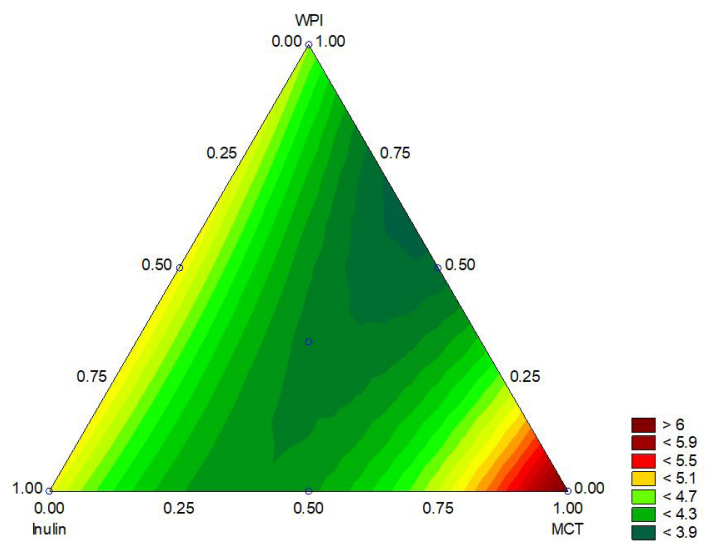

Figure 2. Response surface plot obtained by experimental model for droplet size after 24 hours of refrigerated storage $\left(4^{\circ} \mathrm{C}\right)$. WPI: whey protein isolate; MCT: medium-chain triglycerides (palm kernel oil). 


\subsection{Protein digestibility}

The degree of hydrolysis (DH) of the intact formulas did not differ, presenting an average value of $5.17 \pm 0.46 \%$. However, after digestion, the values were between 15.27 and $19.01 \%$. Peptide distribution, before and after digestion, demonstrated that in all formulas, larger peptides $(>10 \mathrm{kD})$ were predominant in the intact product, due to the mean molecular weight of the main whey proteins ( $\beta$-lactoglobulin with $18.3 \mathrm{kD}$ and $\alpha$-lactoalbumin with $14.2 \mathrm{kD}$ ) (Jambrak et al., 2014). However, after digestion, smaller peptides predominated, especially below $0.4 \mathrm{kD}$, a fraction in which most of the di-tripeptides and free amino acids occur, which are the most available for intestinal absorption (Silvestre et al., 2011) (Table 3).

To evaluate the influence of the three ingredients on the in vitro digestion of proteins, the significance of the proposed quadratic mathematical model for $\mathrm{DH}$ responses and F1, F3, and F4 fractions, after in vitro digestion, were evaluated (Figure 3 ).

For DH, the values obtained by the mathematical model explained about $97 \%$ of the results. This demonstrates that all ingredients considerably contributed to increased DH, as well as the interaction between inulin and WPI. In contrast, MCT and WPI interaction had a negative influence. Among the pure components, inulin provided a smaller increase in hydrolysis degree, with the lowest coefficient, demonstrated by the response surface plot (Figure 3A).

This influence may be due to the ability of inulin to gelation, which could interfere with the access of enzymes to immobilized proteins in gel network, thereby reducing the release of peptides and free amino acids (Luo et al., 2015; Simsek et al., 2017). The impact of food matrices was evaluated by Luo et al. (2015), who observed that, in solution, both whey and egg white proteins had faster digestion, with a higher degree of hydrolysis, compared to a gel matrix.

Digestibility was evaluated according to the distribution of peptides through analysis of fractions F1, F3, and F4, obtained after in vitro digestion. They are more representative of the hydrolysis process, and in intact formulas, for the same fraction, the differences were not pronounced.

Considering the $\mathrm{F} 1$ fraction ( $>8.5 \mathrm{kD}$, large peptides), higher WPI contents (as a pure component or in interaction with inulin) provided higher residual content of large peptides, whereas inulin and MCT alone led to lower content (Figure 3B). However, for all formulas, the levels of large peptides remained below $1.0 \%$, whereas for intact formula, the mean levels were $92.4 \%$ (Table 3 ). However, for the $\mathrm{F} 3$ fraction $(0.4 \mathrm{kD}-3.5 \mathrm{kD})$, the interaction between MCT and WPI was not significant ( $p=0.27)$, which confirms the minor importance of this combination for protein breakage (Figure 3C). Inulin as a pure component promoted higher peptide content, in the range of 0.4 to $3.5 \mathrm{kD}$ (higher coefficient), and lower, in the range of less than $0.4 \mathrm{kD}(\mathrm{F} 4)$, which demonstrates its influence on protein digestibility. According to the degree of hydrolysis data, this ingredient negatively affected the release of small peptides and free amino acids.

The use of MCT or WPI alone promoted higher coefficients for F4 (19.34 and 18.27, respectively) than for F3, demonstrating
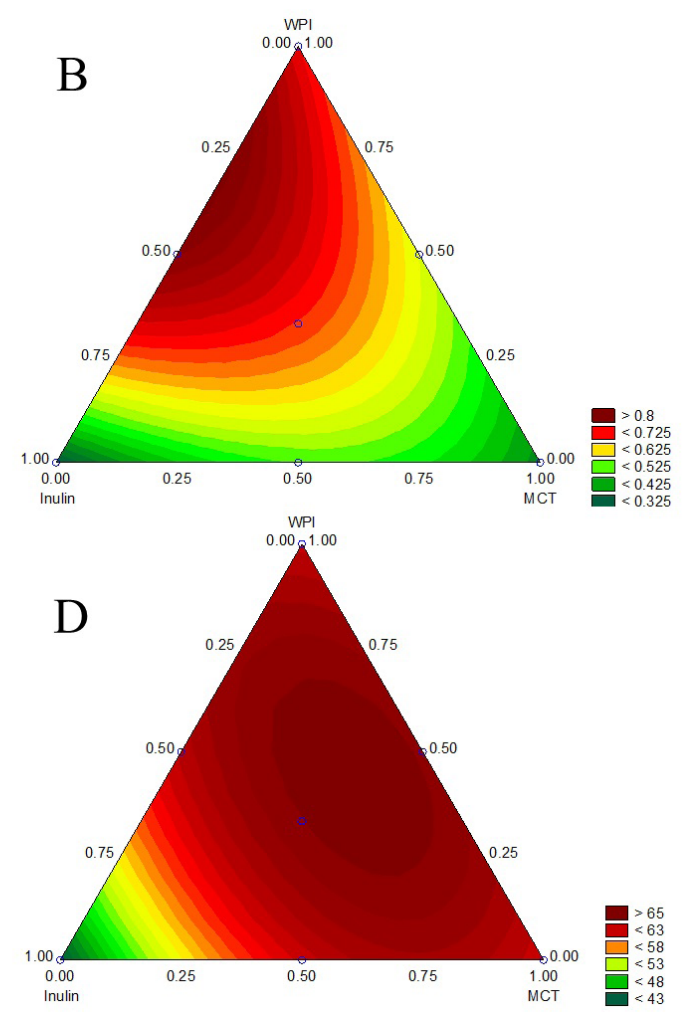

Figure 3. Response surface plot obtained by experimental model for Degree of Hydrolysis (A); F1 (B); F3 (C); F4 (D). WPI: whey protein isolate; MCT: medium-chain triglycerides (palm kernel oil). 


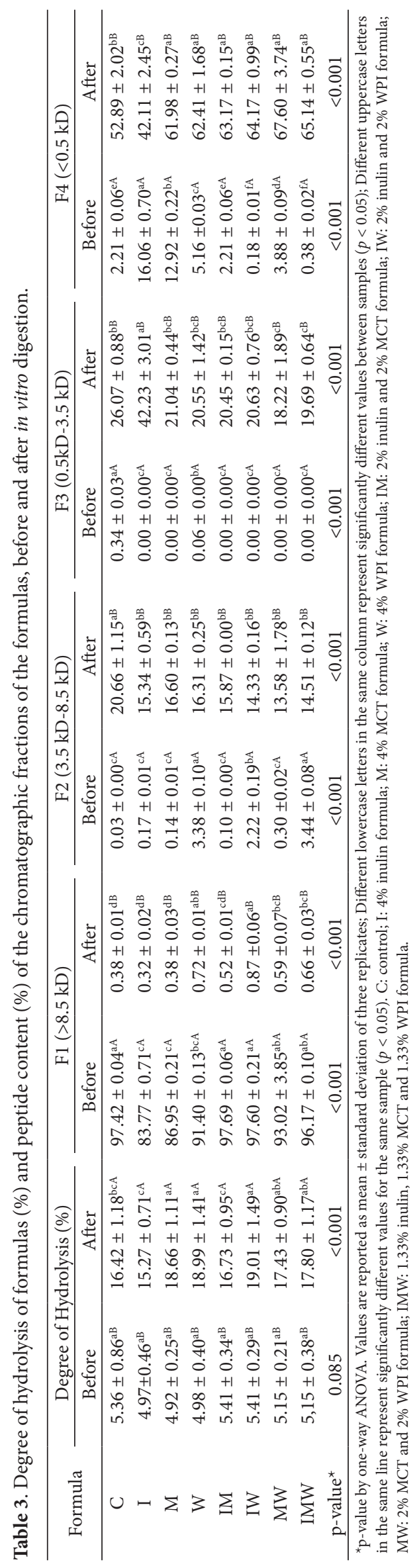


larger release of small peptides and free amino acids. Interactions among the factors were also significant, but with a lower effect on F3 and F4 (Figure 3C and 3D).

Fraction F4 represents the small peptides, in which most of the di-tripeptides are present, as well as the free amino acids. For this response, all factors and their interactions were significant, with the greatest influence given by pure MCT and WPI components, and least for inulin (Figure 3D).

Microstructure and processing of the food matrix are important factors that interfere with the digestion process and modify the release and absorption kinetics of nutrients, especially proteins (Rinaldi et al., 2014; Simsek et al., 2017). The impact of the structure of infant formulas on proteolysis, during in vitro digestion, was investigated by Bourlieu et al. (2015). They found that a minimally processed emulsion promoted a slower rate of protein digestion than in processed (homogenized and/or pasteurized) formulas, concluding that it is extremely relevant to evaluate how the structure of food influences digestion.

Simsek et al. (2017) evaluated three types of inulin (native, short-chain, and long-chain) on the release of peptides during in vitro digestion of low-fat caprines' milk kefir. They found no influence of the different types of inulin on the degree of digestion after duodenal phase, indicating complete hydrolysis of all milk proteins to smaller fragments, as detected by gel electrophoresis (SDS-PAGE), a different technique from that used in the present study. That technique was not able to produce quantitative differences for short peptides, containing less than five amino acid residues.

Our results are difficult to compare with data from the literature, considering that in vitro protocols vary widely. However, the method used (Minekus et al., 2014) is now considered the most reliable procedure to assess in vitro digestibility (Azzollini et al., 2018). Besides that, no other study evaluated the impact of different ingredients on digestibility of enteral formulas.

\subsection{Multi-response optimization}

The optimization for simultaneous responses was done numerically, according to the desirability function (Derringer \& Suich, 1980), using Design-Expert Software 11 (Stat-Ease, USA). The best combination of factors including minimum particle size after $24 \mathrm{~h}$ of refrigerated storage $\left(4^{\circ} \mathrm{C}\right)$; minimum $\mathrm{F} 1$ fraction after digestion (less large peptides); and maximum values of $\mathrm{DH}$ and $\mathrm{F} 4$ fraction after digestion. The numerical analysis suggested the formula with $0.70 \mathrm{~g}$ of inulin, $1.56 \mathrm{~g}$ of MCT, and $1.73 \mathrm{~g}$ of WPI, per $100 \mathrm{~g}$, with an optimized product with a $d$-value $=0.769$.

\section{Conclusion}

The ingredient replacement in enteral formulas significantly affected their nutritional composition, emulsion stability, and protein digestibility. Overall, the addition of MCT with inulin and WPI was beneficial to the emulsion stability of the product, while in those enriched with inulin, there was a reduced content of small peptides, related to a smaller digestibility of proteins.
Thus, the desirability function was used to propose an optimized formulation containing $0.70 \mathrm{~g}$ of inulin, $1.56 \mathrm{~g}$ of MCT, and $1.73 \mathrm{~g}$ of WPI, per $100 \mathrm{~g}$ of formula, with an optimized product $(d$-value $=0.769)$. This optimized solution may be recommended for the production of enteral formulas because this has optimal emulsion stability and protein digestibility, which are essential characteristics for a product to be used by patients under special clinical conditions.

\section{Acknowledgements}

This study was financed in part by the Coordenação de Aperfeiçoamento de Pessoal de Nível Superior - Brasil (CAPES) Finance Code 001 and was supported by grants from Pró-Reitoria de Pesquisa - PRPq - UFMG.

\section{References}

Abrahão, V. (2012). Nourishing the dysfunctional gut and whey protein. Current Opinion in Clinical Nutrition and Metabolic Care, 15(5), 480-484. http://dx.doi.org/10.1097/MCO.0b013e328356b71e. PMid:22878241.

Aguilera, J. M. (2018). The food matrix: implications in processing, nutrition and health. Critical Reviews in Food Science and Nutrition, 58, 1-18. http://dx.doi.org/10.1080/10408398.2018.1502743. PMid:30040431.

Ahmadi, S. F., Nasirpour, A., Goli, S. A. H., \& Riahi, E. (2018). Effect of heat treatment and solution preparation procedure on colloidal stability of whey protein sour cherry beverage. International Journal of Dairy Science, 71(3), 781-790.

Alves, E. P., Morioka, L. R. I., \& Suguimoto, H. H. (2019). Comparison of bioethanol and beta-galactosidade production by Kluyveromyces and Saccharomyces strains grown in cheese whey. International Journal of Dairy Science, 72(3), 409-415.

Association of Official Analytical Chemists - AOAC. (2012). Official methods of analysis of AOAC International (19th ed.). Gaithersburg: AOAC International.

Aydinol, P., \& Ozcan, T. (2018). Production of reduced-fat Labneh cheese with inulin and $\beta$-glucan fibre-based fat replacer. International Journal of Dairy Technology, 71(2), 362-671. http://dx.doi.org/10.1111/14710307.12456.

Azzollini, D., Derossi, A., Fogliano, V., Lakemond, C. M. M., \& Severini, C. (2018). Effects of formulation and process conditions on microstructure, texture and digestibility of extruded insect-riched snacks. Innovative Food Science \& Emerging Technologies, 45, 344353. http://dx.doi.org/10.1016/j.ifset.2017.11.017.

Bourlieu, C., Ménard, O., De La Chevasnerie, A., Sams, L., Rousseau, F., Madec, M.-N., Robert, B., Deglaire, A., Pezennec, S., Bouhallab, S., Carrière, F., \& Dupont, D. (2015). The structure of infant formulas impacts their lipolysis, proteolysis and disintegration during in vitro gastric digestion. Food Chemistry, 182, 224-235. http://dx.doi. org/10.1016/j.foodchem.2015.03.001. PMid:25842331.

Brasil. Agência Nacional de Vigilância Sanitária - ANVISA. (2015, May 15). Dispõe sobre o regulamento técnico de fórmulas para nutrição enteral (Resolução-RDC n 21 de 13 de maio de 2015). Diário Oficial [da] República Federativa do Brasil.

Brown, B., Roehl, K., \& Betz, M. (2015). Enteral nutrition formula selection: current evidence and implications for practice review of enteral nutrition formulations. Nutrition in Clinical Practice, 30(1), 72-85. http://dx.doi.org/10.1177/0884533614561791. PMid:25516537. 
Castagnaro, D., Gadotti, G., Machado, C. I., Tagliari, M. P., \& Silva, M. A. S. (2013). Estabilidade físico-química de formulações para nutrição parenteral neonatal manipuladas em hospital universitário. Revista de Ciências Farmacêuticas Básica e Aplicada, 34(2), 275-280.

Derringer, G., \& Suich, R. (1980). Simultaneous optimization of several response variables. Journal of Quality Technology, 12(4), 214-219. http://dx.doi.org/10.1080/00224065.1980.11980968.

Food and Agriculture Organization - FAO, \& World Health Organization - WHO. (2001). Standard for named vegetable oils - Codex Stan 210-1999 (Report of a Joint FAO/WHO Codex Alimentarius Commission). Rome: FAO.

Generoso, S. V., Lages, P. C., \& Correia, M. I. T. D. (2016). Fiber, prebiotics, and diarrhea: what, why, when and how. Current Opinion in Clinical Nutrition and Metabolic Care, 19(5), 388-393. http:// dx.doi.org/10.1097/MCO.0000000000000311. PMid:27428350.

González-Martínez, D. A., Carrillo-Navas, H., Barrera-Díaz, C. E., Martínez-Vargas, S. L., Alvarez-Ramírez, J., \& Pérez-Alonso, C. (2017). Characterization of a novel complex coacervate based on whey protein isolate-tamarind seed mucilage. Food Hydrocolloids, 72, 115-126. http://dx.doi.org/10.1016/j.foodhyd.2017.05.037.

Guimarães, J. T., Silva, E. K., Alvarenga, V. O., Costa, A. L. R., Cunha, R. L., Sant'ana, A. S., Freitas, M. Q., Meireles, A. A., \& Cruz, A. G. (2018a). Physicochemical changes and microbial inactivation after high-intensity ultrasound processing of prebiotic whey beverage applying different ultrasonic power levels. Ultrasonics Sonochemistry, 44, 251-260. http://dx.doi.org/10.1016/j.ultsonch.2018.02.012. PMid:29680610.

Guimarães, J. T., Silva, E. K., Costa, A. L. R., Cunha, R. L., Freitas, M. Q., Meireles, M. A. A., \& Cruz, A. G. (2018b). Manufacturing a prebiotic whey beverage exploring the influence of degree of inulin polymerization. Food Hydrocolloids, 77, 787-795. http://dx.doi. org/10.1016/j.foodhyd.2017.11.021.

Guimarães, J. T., Silva, E. K., Ranadheera, C. S., Moraes, J., Raices, R. S. L., Silva, M. C., Ferreira, M. S., Freitas, M. Q., Meireles, M. A. A., \& Cruz, A. G. (2019). Effect of high-intensity ultrasound on the nutritional profile and volatile compounds of a prebiotic soursop whey beverage. Ultrasonics Sonochemistry, 55, 157-164. http://dx.doi. org/10.1016/j.ultsonch.2019.02.025. PMid:30853535.

Jakobsen, L. H., Wirth, R., Smoliner, C., Klebach, M., Hofman, Z., \& Kondrup, J. (2017). Gastrointestinal tolerance and plasma status of carotenoids, EPA and DHA with a fiber-enriched tube feed in hospitalized patients initiated on tube nutrition: randomized controlled trial. Clinical Nutrition (Edinburgh, Lothian), 36(2), 380388. http://dx.doi.org/10.1016/j.clnu.2016.02.001. PMid:27126710.

Jambrak, A. R., Mason, T. J., Lelas, V., Paniwnyk, L., \& Herceg, Z. (2014). Effect of ultrasound treatment on particle size and molecular weight of whey proteins. Journal of Food Engineering, 121(1), 15-23. http:// dx.doi.org/10.1016/j.jfoodeng.2013.08.012.

Karnopp, A. R., Oliveira, K. G., Andrade, E. F., Postingher, B. M., \& Granato, D. (2017). Optimization of an organic yogurt based on sensorial, nutritional, and functional perspectives. Food Chemistry, 233, 401-411. http://dx.doi.org/10.1016/j.foodchem.2017.04.112. PMid:28530591.

Kinsella, R., Maher, T., \& Clegg, M. E. (2017). Coconut oil has less satiating properties than medium chain triglyceride oil. Physiology \& Behavior, 179, 422-426. http://dx.doi.org/10.1016/j.physbeh.2017.07.007. PMid:28689741.

Li, S., Sijtsema, S. J., Kornelis, M., Liu, Y., \& Li, S. (2019). Customer confidence in the safety of milk and infant milk formula in China. Journal of Dairy Science, 102(10), 8807-8818. http://dx.doi.org/10.3168/ jds.2019-16638. PMid:31421878.
López-Castejón, M. L., Bengoechea, C., Espinosa, S., \& Carrera, C. (2019). Food hydrocolloids characterization of prebiotic emulsions stabilized by inulin and $\beta$ - lactoglobulin. Food Hydrocolloids, 87, 382-393. http://dx.doi.org/10.1016/j.foodhyd.2018.08.024.

Luo, Q., Boom, R. M., \& Janssen, A. E. M. (2015). Digestion of protein and protein gels in simulated gastric environment. LebensmittelWissenschaft + Technologie, 63(1), 161-168. http://dx.doi.org/10.1016/j. lwt.2015.03.087.

Marten, B., Pfeuffer, M., \& Schrezenmeir, J. (2006). Medium-chain triglycerides. International Dairy Journal, 16(11), 1374-1382. http:// dx.doi.org/10.1016/j.idairyj.2006.06.015.

Mat, D. J. L., Le Feunteun, S., Michon, C., \& Souchon, I. (2016). In vitro digestion of foods using $\mathrm{pH}$-stat and the INFOGEST protocol: Impact of matrix structure on digestion kinetics of macronutrients, proteins and lipids. Food Research International, 88, 226-233. http:// dx.doi.org/10.1016/j.foodres.2015.12.002.

Minekus, M., Alminger, M., Alvito, P., Ballance, S., Bohn, T., Bourlieu, C., Carrière, F., Boutrou, R., Corredig, M., Dupont, D., Dufour, C., Egger, L., Golding, M., Karakaya, S., Kirkhus, B., Le Feunteun, S., Lesmes, U., Macierzanka, A., Mackie, A., Marze, S., McClements, D. J., Ménard, O., Recio, I., Santos, C. N., Singh, R. P., Vegarud, G. E., Wickham, M. S. J., Weitschies, W., \& Brodkorb, A. (2014). A standardised static in vitro digestion method suitable for food - an international consensus. Food \& Function, 5(6), 1113-1124. http:// dx.doi.org/10.1039/C3FO60702J. PMid:24803111.

Moghadam, B. E., Keivaninahr, F., Fouladi, M., Mokarran, R. R., \& Nazemi, A. (2019). Inulin addition to yogurt: prebiotic activity, health effects and sensory properties. International Journal of Dairy Technology, 72(2), 183-198. http://dx.doi.org/10.1111/1471-0307.12579.

Mohan, A., McClements, D. J., \& Udenigwe, C. C. (2016). Encapsulation of bioactive whey peptides in soy lecithin-derived nanoliposomes: Influence of peptide molecular weight. Food Chemistry, 213, 143-148. http://dx.doi.org/10.1016/j.foodchem.2016.06.075. PMid:27451165.

Monteiro, S. H. M. C., Silva, E. K., Alvarenga, V. O., Moraes, J., Freitas, M. Q., Silva, M. C., Raices, R. S. L., Sant'ana, A. S., Meireles, M. A. A., \& Cruz, A. G. (2018). Effects of ultrasound energy density on the non-thermal pasteurization of chocolate milk beverage. Ultrasonics Sonochemistry, 42, 1-10. http://dx.doi.org/10.1016/j. ultsonch.2017.11.015. PMid:29429649.

Morais, H. A., Silvestre, M. P. C., Silva, M. R., Silva, V. D. M., Batista, M. A., Simões e Silva, A. C., \& Silveira, J. N. (2015). Enzymatic hydrolysis of whey protein concentrate: effect of enzyme type and enzyme:substrate ratio on peptide profile. Journal of Food Science and Technology, 52(1), 201-210. http://dx.doi.org/10.1007/s13197013-1005-z.

Mugele, R. A., \& Evans, H. D. (1951). Droplet size distribution in sprays. Industrial \& Engineering Chemistry, 43(6), 1317-1324. http://dx.doi. org/10.1021/ie50498a023.

Nishanthi, M., Chandrapala, J., \& Vasiljevic, T. (2018). Impact of storage conditions on solubility, heat stability and emulsifying properties of selected spray dried whey protein concentrates. LebensmittelWissenschaft + Technologie, 92, 16-21. http://dx.doi.org/10.1016/j. lwt.2018.01.068.

Pei, X., Li, Y., Zhang, H., Zhan, L., Yu, X., Lan, G., Jia, H., Li, N., Yang, D., \& Mei, L. (2019). Surveillance and characterization of Cronobacter in powdered infant formula processing factories. Food Control, 96, 318-323. http://dx.doi.org/10.1016/j.foodcont.2018.09.009.

Portela, J. B., Coimbra, P. T., Cappato, L. P., Alvarenga, V. O., Oliveira, R. B. A., Pereira, K. S., Azeredo, D. R. P., Sant'ana, A. S., Nascimento, J. S., \& Cruz, A. G. (2019). Predictive model for inactivation of salmonella 
in infant formula during microwave heating process. Food Control, 104, 308-312. http://dx.doi.org/10.1016/j.foodcont.2019.05.006.

Rinaldi, L., Gauthier, S. F., Britten, M., \& Turgeon, S. L. (2014). In vitro gastrointestinal digestion of liquid and semi-liquid dairy matrixes. Lebensmittel-Wissenschaft + Technologie, 57(1), 99-05. http://dx.doi. org/10.1016/j.lwt.2014.01.026.

Savino, P. (2018). Knowledge of constituent ingredients in enteral nutrition formulas can make a difference in patient response to enteral feeding. Nutrition in Clinical Practice, 33(1), 90-98. PMid:28841088.

Shimokawa, K., Nagasaka, Y., Sawa, M., Wada, Y., \& Ishii, F. (2017). Physicochemical properties and stability of the emulsion prepared with various emulsifiers for enteral nutrition preparations. Journal of Dispersion Science and Technology, 38(8), 1221-1226. http://dx.doi. org/10.1080/01932691.2016.1230066.

Silva, E. K., Guimarães, J. T., Costa, A. L. R., Cruz, A. G., \& Meireles, M. A. A. (2019). Non-thermal processing of inulin-enriched soursop whey beverage using supercritical carbon dioxide technology. The Journal of Supercritical Fluids, 154, 104635. http://dx.doi.org/10.1016/j. supflu.2019.104635.

Silva, M. R., Silvestre, M. P. C., Silva, V. D. M., Souza, M. W. S., Lopes, C. O. Jr., Afonso, W. O., Lana, F. C., \& Rodrigues, D. F. (2014). Production of ace-inhibitory whey protein concentrate hydrolysates: Use of pancreatin and papain. International Journal of Food Properties, 17(5), 1002-1012. http://dx.doi.org/10.1080/10942912.2012.685821.

Silvestre, M. P. C., Afonso, W. O., Lopes, C. O. Jr., Silva, V. D. M., Morais, H. A., Souza, M. W. S., \& Silva, M. R. (2011). Use of subtilisin and pancreatin for hydrolyzing whey protein concentrate. American Journal of Food Technology, 6(8), 647-660. http://dx.doi.org/10.3923/ ajft.2011.647.660.

Silvestre, M. P. C., Decker, E. A., \& McClements, D. J. (1999). Influence of copper on the stability of whey protein stabilized emulsions. Food Hydrocolloids, 13(5), 419-424. http://dx.doi.org/10.1016/ S0268-005X(99)00027-2.

Simsek, S., Sánchez-Rivera, L., El, S. N., Karakaya, S., \& Recio, I. (2017). Characterisation of in vitro gastrointestinal digests from low fat caprine kefir enriched with inulin. International Dairy Journal, 75, 68-74. http://dx.doi.org/10.1016/j.idairyj.2017.07.004.

Sriprablom, J., Luangpituksa, P., Wongkongkatep, J., Pongtharangkul, T., \& Suphantharika, M. (2019). Influence of pH and ionic strength on the physical and rheological properties and stability of whey protein stabilized o/w emulsions containing xanthan gum. Journal of Food Engineering, 242, 141-152. http://dx.doi.org/10.1016/j. jfoodeng.2018.08.031.

Teimouri, S., Abbasi, S., \& Scanlon, M. G. (2018). Stabilization mechanism of various inulins and hydrocolloids: milk-sour cherry juice mixture. International Journal of Dairy Technology, 71(1), 208-215. http:// dx.doi.org/10.1111/1471-0307.12376.

Trindade, M. B., Soares, B. C. V., Scudino, H., Guimarães, J. T., Esmerino, E. A., Freitas, M. Q., Pimentel, T. C., Silva, M. C., Souza, S. L. Q., Almada, R. B., \& Cruz, A. G. (2019). Cheese whey exploitation in Brazil: a questionnaire survey. Food Science and Technology (Campinas), 39(3), 788-791. http://dx.doi. $\operatorname{org} / 10.1590 /$ fst.07419.

Vieira, M. M. C., Santos, V. F. N., Bottoni, A., \& Morais, T. B. (2018). Nutritional and microbiological quality of commercial and homemade blenderized whole food enteral diets for homebased enteral nutritional therapy in adults. Clinical Nutrition (Edinburgh, Lothian), 37(1), 177-181. http://dx.doi.org/10.1016/j. clnu.2016.11.020. PMid:28003040.

Wang, S., Shi, Y., Tu, Z., Zhang, L., Wang, H., Tian, M., \& Zhang, N. (2017). Influence of soy lecithin concentration on the physical properties of whey protein isolate-stabilized emulsion and microcapsule formation. Journal of Food Engineering, 207, 73-80. http://dx.doi. org/10.1016/j.jfoodeng.2017.03.020.

Zhuang, K., Li, H., Zhang, Z., Wu, S., Zhang, Y., Fox, E. M., Man, C., \& Jiang, Y. (2019). Typing and evaluating heat resistance of Bacillus cereus sensu stricto isolated from the processing environment of powdered infant formula. Journal of Dairy Science, 102(9), 77817793. http://dx.doi.org/10.3168/jds.2019-16392. PMid:31255274. 


\section{Supplementary Material}

Supplementary material accompanies this paper.

Legend S1. Example of size-exclusion chromatogram of enteral formula sample after simulated in vitro digestion.

This material is available as part of the online article from http://www.scielo.br/cta 